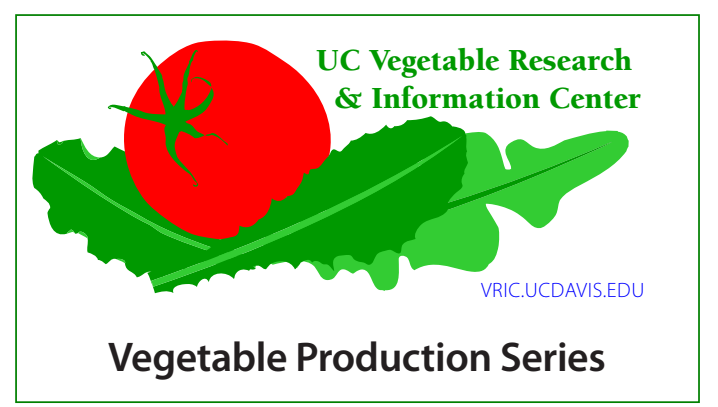

\section{CANTALOUPE PRODUCTION IN CALIFORNIA}

TIM HARTZ and MARITA CANTWELL, University of California Cooperative Extension Specialists, Department of Plant Sciences, University of California, Davis; JAN MICKLER, SHANNON MUELLER, SCOTT STODDARD, and TOM TURINI, University of California Cooperative Extension Farm Advisors

\section{PRODUCTION AREAS AND SEASONS}

California has two primary cantaloupe (or muskmelon; Cucumis melo L.) production areas: the southern desert valleys in Imperial and Riverside Counties and the San Joaquin Valley (Fresno, Kern, Kings, Merced, and Stanislaus Counties). Melons in the southern desert valleys are planted from late December through March for harvest from May through early July. In the San Joaquin Valley, planting begins in February in the south and continues northward through July; harvest begins in late June and continues into October. Overall, plantings are timed to provide a continuous supply of melons from May through October.

\section{CANTALOUPE ACREAGE AND VALUE}

\begin{tabular}{|c|c|c|c|}
\hline Year & Acreage & $\begin{array}{c}\text { Average yield } \\
\text { (tons/acre) }\end{array}$ & $\begin{array}{c}\text { Gross value/ } \\
\text { acre }\end{array}$ \\
\hline 2004 & 48,000 & 13.8 & $\$ 3,800$ \\
\hline 2005 & 48,000 & 12.8 & $\$ 3,490$ \\
\hline 2006 & 49,000 & 11.3 & $\$ 4,650$ \\
\hline
\end{tabular}

Source: USDA National Agricultural Statistics Service, http:/ / www.nass.usda.gov.

\section{CLIMATIC REQUIREMENTS}

Cantaloupe is a warm-season annual plant that is sensitive to freezing temperatures at any growth stage. Growth is very slow below $60^{\circ} \mathrm{F}\left(16^{\circ} \mathrm{C}\right)$ and optimal from $85^{\circ}$ to $95^{\circ} \mathrm{F}\left(30^{\circ}\right.$ to $\left.35^{\circ} \mathrm{C}\right)$. Cantaloupe can tolerate temperatures in excess of $104^{\circ}\left(40^{\circ} \mathrm{C}\right)$. Since fruit set requires bee pollination, weather conditions that reduce bee activity (cold, rain, high wind, or prolonged cloud coverage) may reduce yield.

\section{VARIETIES AND PLANTING TECHNIQUES}

Hybrid cantaloupe varieties dominate both production areas. In the southern desert valleys varieties are chosen based on earliness and high yield potential under stressful spring conditions. Commonly used hybrids include Impac, Gold Rush, Navigator, and Gold Express. In the San Joaquin Valley hybrid varieties such as Oro Rico, Archer, Gold Express, and Durango are common; TopMark and other openpollinated lines are seldom used. Statewide, virtually all cantaloupes are direct seeded.

Growers in the southern desert valleys use several specialized techniques to promote earliness. A widely used planting system is the mid-bed trench, which involves using a bed shaper to produce a trench, or groove, in the center of an 80-inch (2-m) bed. A single line of seed is planted in the trench, which is then capped with a sheet of clear polyethylene. This system stimulates early growth and provides some frost protection. At thinning the polyethylene is ventilated, then removed; the trench area is weeded and the bed is reshaped into a standard configuration. Slant-bed culture, in which sloping 80 -inch (2-m) beds are oriented east-west, is also commonly used. One row of seed is planted on the south-facing slope of the bed; increased soil temperature from solar heating stimulates seed germination. After crop establishment, the bed is reshaped to leave the plant row centered on a standard 80-inch bed.

In the San Joaquin Valley fields are generally preirrigated, either by furrow or sprinkler, to ensure a full soil moisture profile. When dry enough for tillage, fields are worked into either 40 -inch or 80 -inch (1- or 2-m) raised beds. A single seed line is planted per bed. Seed is planted into moist soil just below the tilled zone, with 3 to 6 inches $(7.5$ to $15 \mathrm{~cm})$ of loose

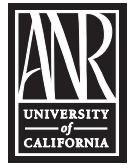

UNIVERSITY OF CALIFORNIA

Division of Agriculture and Natural Resources

http://anrcatalog.ucdavis.edu

Publication 7218 
soil over the seeded row to retain moisture. After seed germination, this soil "cap" is removed. Where 40-inch beds are used, every second bed is seeded; after thinning, the unused bed is split and tilled to widen the planted bed to 80 inches with the plant row in the center.

Statewide, seeding rates vary from 0.5 to 1.0 pound per acre ( 0.6 to $1.1 \mathrm{~kg} / \mathrm{ha})$ for hybrid varieties, and 1 to 2 pounds per acre (1.1 to $2.2 \mathrm{~kg} / \mathrm{ha}$ ) for open-pollinated varieties. Desired final in-row spacing is 8 to 16 inches (20 to $40 \mathrm{~cm}$ ).

\section{SOILS}

Many soil textures are used for cantaloupe production. Sandy soils are used for the earliest plantings because they warm more rapidly in the spring. Loam and clay loam soils are preferred for main-season production due to greater water-holding capacity, which favors a prolonged harvest period. Regardless of texture, all cantaloupe soils should be well drained, since the crop is sensitive to root diseases that thrive in poorly aerated soils.

\section{IRRIGATION}

The majority of California cantaloupe fields are furrow irrigated. Two to five irrigations are used (depending on region and soil type) after crop establishment, the last one 7 to 10 days before the initiation of harvest. Excessive irrigation late in the season can compromise fruit quality and increase the severity of root disease. Under representative California conditions, cantaloupe consumes about 10 to 15 inches (250 to $375 \mathrm{~mm}$ ) of water. Seasonal water applications vary considerably, depending on irrigation efficiency, leaching requirements, and the need for pre-irrigation. Drip irrigation is becoming increasingly popular for cantaloupe production; at least 20 percent of cantaloupe acreage is now drip irrigated. Drip irrigation lines are typically buried in the center of the soil beds; the systems may be renovated each production season or left in place for a number of years, depending on the grower's management scheme and crop rotation. Drip irrigation scheduling is determined by potential evapotranspiration $\left(\mathrm{ET}_{\mathrm{o}}\right)$ estimates and crop growth stage; frequency of irrigation can vary from once a week early in the season to daily during times of peak water demand. Some growers use drip irrigation lines placed in every other furrow after crop establishment. While this approach may not provide the full yield potential of a buried, in-row system, it does provide improved irrigation control compared with furrow irrigation, and the system is portable, which eliminates management issues associated with crop rotation. Regardless of irrigation technique, care must be taken to keep the tops of the beds dry to min- imize fruit contact with moist soil, which can result in unsightly ground spots and fruit rots.

\section{FERTILIZATION}

Cantaloupe has modest nutrient needs. Typical fertilizer application rates are 80 to 150 pounds per acre (90 to $168 \mathrm{~kg} / \mathrm{ha}$ ) of nitrogen (N) and 40 to 200 pounds per acre (45 to $225 \mathrm{~kg} / \mathrm{ha}$ ) of $\mathrm{P}_{2} \mathrm{O}_{5}$. In general, fertilization rates are higher in the southern desert areas than in the San Joaquin Valley. Phosphorus (P) and a small amount of $\mathrm{N}$ are applied preplant, with the remaining $\mathrm{N}$ applied as a sidedressing after thinning or in irrigation water. In the southern desert valleys and the San Joaquin Valley, soil potassium (K) levels are usually sufficient for melon production, except in sandy soils with extractable K levels below 100 ppm. Application of microelements is not generally required, with the exception of zinc, which may be needed in some San Joaquin Valley soils.

\section{POLLINATION}

At least one colony of bees per acre is required for optimal cantaloupe yields. Honey bees are the only efficient pollinators of melons; approximately 10 to 15 bee visits are required to adequately pollinate a bisexual (fruit-producing) melon flower. Distribution of bee colonies around the field is important, since research has shown that bee activity and yield decline with distances over 600 feet $(180 \mathrm{~m})$ from the colony. Bee colonies should be set out just prior to the appearance of bisexual flowers and remain in place for 2 to 3 weeks. Care in pesticide usage during this period is critical to minimize bee kill.

\section{INTEGRATED PEST MANAGEMENT}

Detailed information about IPM for cantaloupe is available in the UC IPM Pest Management Guidelines for Cucurbits, http:/ /www.ipm.ucdavis.edu/PMG/ selectnewpest.cucurbits.html. Herbicides, insecticides, and fungicides should always be used in compliance with label instructions.

\section{Weed Management}

Annual and perennial weeds can be serious problems in cantaloupe production; many weed control practices are used. Some growers use a preplant banded application of a broad-spectrum herbicide in the plant row. Where fields are pre-irrigated and planted in moist soil, cultivation is the primary in-row weed control method. Most fields receive at least one handhoeing, usually in conjunction with thinning of the melon seedlings. A lay-by, incorporated herbicide application is common after thinning to provide season-long weed control in the furrows and edges of the bed. 


\section{Insect Identification and Management}

Cantaloupes are subject to damage by a number of insects. Wireworms (Limonius spp.), cutworms (Athetis mindara and related species), and seed-corn maggots (Delia platura) can damage or kill seedlings. Aphids (Myzus persicae and Aphis gossypii), cucumber beetles (Acalymma and Diabrotica spp.), leafhoppers (Empoasca spp.), leafminers (Liriomyza spp.), and spider mites (Tetranychus spp.) can damage foliage and fruit and may require chemical control. A potentially devastating insect pest is the silverleaf whitefly (Bemisia argentifolii). Its effective range is confined to the southern desert valleys and the southern third of the San Joaquin Valley. Whitefly populations build to damaging levels primarily during late summer or early fall. Although pesticide application may be required, whitefly damage to spring-planted melons is minimal. However, fall production in heavily infested areas is problematic, with control measures expensive and only inconsistently effective. A variety of other minor insect pests occasionally cause economic damage, but they seldom require chemical control.

\section{Disease and Nematode Identification and Management}

Powdery mildew (Podosphaera xanthii and Erysiphe cichoracearum) can occur on susceptible cantaloupe varieties throughout the entire production season and may require chemical control. Downy mildew (Pseudoperonospora cubensis), which requires prolonged presence of free water on leaf surfaces for spores to germinate, is seldom seen, except during rainy periods in the fall in the San Joaquin Valley.

Losses to vascular root diseases such as Verticillium (V. dahliae) and Fusarium (F. oxysporum) wilts are generally minimized by selection of resistant or tolerant varieties. A number of other soilborne diseases can cause substantial crop damage, including Monosporascus root rot (Monosporascus cannonballus), charcoal rot (Macrophomina phaseolina), and sudden wilt (Acremonium cucurbitacearum or Pythium spp.). There is no generally useful chemical control; the root rot complex of organisms is combated by careful water management to minimize root stress, destruction of crop residue immediately following harvest, and good crop rotation. Soil fumigation may reduce losses to soil pests but is seldom an economically viable practice for cantaloupe production.

A complex of aphid-vectored viruses can cause serious economic losses in cantaloupe. The most prevalent viruses are cucumber mosaic virus (CMV), watermelon mosaic virus (WMV), and zucchini yellows mosaic virus (ZYMV). The severity of economic loss varies from season to season and area to area; outbreaks are a function of several factors, but high numbers of migratory aphids are required for an epidemic to occur. Insecticide applications may minimize in-field virus spread but are ineffective in preventing transmission by aphids coming from neighboring fields. Maintaining good sanitation (weed control and rapid plow-down of crop residues) may also minimize virus spread. Providing physical separation of early and late plantings may reduce virus severity in the late plantings. Additionally, whitefly-vectored cucurbit yellows stunt disorder virus (CYSDV) has become established in the southern desert valleys. This virus is most damaging in the fall, when whitefly pressure is highest. Systemic insecticide application to limit whitefly population and the use of insect exclusion techniques such as row covers reduce the likelihood of significant damage to fall melons.

Root knot nematodes (Meloidogyne spp.) can cause devastating losses but are generally confined to lighttextured soils. Preplant treatment is justified if soil sampling or previous crop history suggests the presence of a high nematode population.

\section{HARVESTING AND HANDLING}

Cantaloupes are normally hand-harvested at "fullslip" stage (when the fruit will cleanly separate from the vine with light pressure). Depending on variety, the external color at this stage may still have a greenish cast. Fields are harvested 8 to 10 times over a 10- to 14-day period. Fruit of good quality will have a soluble solids level of at least 10 degrees Brix. Melons are either loaded into bulk trucks for transport to a conventional packing shed or are packed in the field into the industry-standard 40-pound (18-kg) cartons. The fruit are sized mechanically or by sight and packed $9,12,15,18$, or 23 per carton.

\section{POSTHARVEST HANDLING}

Rapid removal of field heat is required to maximize the postharvest life of cantaloupes. The most common approach is forced-air (pressure) cooling. Once properly cooled, cantaloupes can be stored for 2 weeks or more at $34^{\circ}$ to $40^{\circ} \mathrm{F}\left(1^{\circ}\right.$ to $\left.4^{\circ} \mathrm{C}\right)$. Water loss through areas of the surface netting scuffed during harvest and handling can reduce cosmetic quality during storage; the problem is minimized by careful handling and maintenance of high humidity during storage.

\section{MARKETING}

Palletized cartons are shipped primarily by truck to terminal markets and wholesale receivers across the United States and Canada. There are limited exports of California cantaloupe by ocean transport to Pacific Rim nations. 


\section{FOR FURTHER INFORMATION}

To order or obtain ANR publications and other products, visit the ANR Communication Services online catalog at http://anrcatalog.ucdavis.edu or phone 1-800-994-8849. You can also place orders by mail or FAX, or request a printed catalog of our products from

University of California

Agriculture and Natural Resources

Communication Services

6701 San Pablo Avenue, 2nd Floor

Oakland, California 94608-1239

Telephone 1-800-994-8849 or (510) 642-2431

FAX (510) 643-5470

E-mail: danrcs@ucdavis.edu

\section{UCY}

This publication has been anonymously peer reviewed for technical accuracy by University of California scientists and other qualified professionals. This review process was managed by the ANR Associate Editor REVIEWED for Vegetable Crops.

Publication 7218

ISBN-13: 978-1-60107-569-7

(C)1996, 2008 The Regents of the University of California

Division of Agriculture and Natural Resources

All rights reserved.

No part of this publication may be reproduced, stored in a retrieval system, or transmitted, in any form or by any means, electronic, mechanical, photocopying, recording, or otherwise, without the written permission of the publisher and the authors.

The University of California prohibits discrimination or harassment of any person on the basis of race, color, national origin, religion, sex, gender identity, pregnancy (including childbirth, and medical conditions related to pregnancy or childbirth), physical or mental disability, medical condition (cancer-related or genetic characteristics), ancestry, marital status, age, sexual orientation, citizenship, or status as a covered veteran (covered veterans are special disabled veterans, recently separated veterans, Vietnam era veterans, or any other veterans who served on active duty during a war or in a campaign or expedition for which a campaign badge has been authorized) in any of its programs or activities. University policy is intended to be consistent with the provisions of applicable State and Federal laws.

Inquiries regarding the University's nondiscrimination policies may be directed to the Affirmative Action/Staff Personnel Services Director, University of California, Agriculture and Natural Resources, 1111 Franklin Street, $6^{\text {th }}$ Floor, Oakland, CA 94607-5201, (510) 987-0096. For information about ordering this publication, telephone 1-800-994-8849.

To simplify information, trade names of products have been used. No endorsement of named or illustrated products is intended, nor is criticism implied of similar products that are not mentioned or illustrated.

pr-2/08-SB/CR 